\title{
Application Values of Character Education in the Modern Pesantren System and Culture (Study at Pondok Pesantren Modern Ar-Raudlatul Hasanah Medan)
}

\author{
Manshuruddin; Tumiran; Muhammad Yunan \\ University of Pembangunan Panca Budi Medan, Indonesia
}

http://dx.doi.org/10.18415/ijmmu.v8i12.3241

\begin{abstract}
Pondok pesantren today can be said to be the most ideal and potential educational institution in fostering a character that is loaded with education values both religious values and the noble values of the nation. The importance of this research is to find different strategies or patterns that can be used as a reference for the development of character education models for formal schools. This research uses qualitative methods that are descriptive with a research site, namely Modern Pesantren Ar-Raudhatul Hasanah Medan. The results showed that character education in Ar-Raudlatul Hasanah Medan boarding school was carried out systemically-integratively. All center activities from waking up in the morning to going back to sleep at night accumulate in pesantren systems and cultures based on the values of Panca Jiwa, Motto, and Philosophy of Pesantren. The strategy of implementing character education is through integration into kmi curriculum learning activities, the formation of pesantren culture/ culture, and extracurricular activities. The methods carried out are direction, transparency, assignment, training, habituation, discipline, appreciation and punishment.
\end{abstract}

Keywords: Application; Value; Character Education; Pesantren Modern; Culture

\section{Introduction}

The implementation of character education has been running in every school since the last 10 years (Ritonga et al., 2020), but until now it still has not shown the expected results, as intended in the purpose of national education which is to develop the ability and form the character and civilization of a dignified nation in order to educate the life of the nation, aiming to develop the potential of learners to become human beings who believe and fear God YME, Be noble, healthy, knowledgeable, capable, creative, independent, and become a democratic and responsible citizen as the Sisdiknas Law Article 2 of 2003.

Case after case of demoralization that occurs in school-age children such as fighting, drugs, murder, bullying theft, and other negative behaviors realizes to us that there needs to be efforts to improve the education system in shaping the character of learners. According to data sourced from the Indonesian Child Protection Commission (KPAI) there were a number of cases of moral deviation in children. In the last 5 years, between 2016-2020, there were 808 cases of Child Pornographic Media Ownership (HP/Video, etc.), 702 cases of children as Perpetrators of Sexual Violence (Rape / Abuse), 506 cases of Children As Perpetrators of Physical Violence (Persecution, Ganging, Fights, etc.), 360 cases of Child Bulliying Perpetrators on Social Media, 329 cases of Child Perpetrators of Student Tawuran, 263 cases of 
Children Of Drug Users (Narcotics, Cigarettes, Liquor, etc.), 252 cases of Children As Perpetrators of Theft, and 247 Children as Perpetrators of Murder (source: KPAI R.N - May 18, 2021).

Some of the factors that cause the lack of success in the implementation of character education to date are (1) education too emphasis on the intellectual aspect as a measure of success, so that the formation of good character is neglected (Fakhruddin, 2014), (2) the absence of the application of character education as a whole, but simply fulfilling teaching obligations, without knowing how it should be (Zuchdi, 2010), (3) children have not got a model that can be a role model (Guntur, 2017) According to Suryadi that the main cause of moral and character crisis among learners, graduates, educators, even education managers, is the occurrence of cotomization, namely the strict separation between intellectual education on the one hand and value education on the other (Suryadi, 2012). In fact, if based on Bloom's theory there are three domains in learning, namely cognitive, affective, and psychomotor. (Rusman, 2012). Similarly, in terms of character education, according to Lickona quoted from Rasdi Ekosiswoyo in his writing mentioned that schools should develop three important aspects in the formation of good character of learners, namely moral knowledge, moral feelings, and moral behavior (Rasdi Ekosiswoyo, 2017).

Currently, the educational institution that is consistent and potential in educating and shaping the morale of learners is pesantren. Pesantren is a unique educational institution, including because of the system, culture, and methods applied by the institution. In addition, pesantren is also an educational institution that can play the role of empowerment and transformation of civil society effectively, and touch all dimensions of life that focus on instilling the values of the character of the nation based on religion.

The importance of this research is to uncover (1) the essential values that animate character education for students in modern boarding schools, (3) character values developed in modern pesantren ar-Raudlatul Hasanah Medan, (2) strategies and methods in the implementation of character education for students in modern boarding schools Ar-Raudlatul Hasanah Medan. The results of this research can later be used as a basis and pattern in redesigning and contextualizing for pesantren educational institutions, especially including formal school institutions in internalizing character values for learners.

\section{Research Method}

This research uses qualitative methods that are descriptive with a research site, namely Modern Pesantren Ar-Raudhatul Hasanah Medan. Data collection techniques through non-participatory observations, in-depth interviews and documentation studies. Data analysis techniques using milles \&huberman interactive analysis model through data reduction, data display and conclusion withdrawal. In this study, researchers explored character values inherent in the daily activities and behaviors of santri in the modern pesantren education system. Furthermore, the meaning, interpretation, and conclusion of the process of actualization and implementation of character education in modern boarding schools. The validity of data uses the triangulation of sources and techniques. Determination of subjects using snowball sampling techniques, namely pesantren caregivers, some teachers / ustadz, and santri.

\section{Result and Analysis}

\section{A. Essential Values That Animate the Implementation of Character Education in Pesantren Ar- Raudlatul Hasanah}

Every educational institution including pesantren has values that underlie or animate the implementation of education in it. Likewise with pesantren Ar-Raudlatul Hasanah, in carrying out education, especially with regard to the formation of santri character in addition to referring to vision and mission, also based on Panca Jiwa Pesantren. All activities and lives in Pesantren Ar-Raudlatul Hasanah are based on the essential values summarized in the Panca Jiwa, namely as follows: 


\section{Sincerity}

It means doing something not because it is driven by a desire to get a certain profit. All deeds are done with the intention solely of worship, lillah. In pesantren created a strong miliu in reflecting the value of sincerity. The Waqf Agency sincerely protects without expecting anything from pesantren, sincere leaders work despite their busy time, the Assembly of Caregivers sincerely educates and teachers are sincere in helping to carry out the process of education and teaching, the students are sincerely educated and the guardians also sincerely hand over their sons and daughters completely to pesantren to be educated. This soul creates an atmosphere of harmonious Pesantren life between the respected Waqf Agency, the Leader and The Assembly of Caregivers and respected teachers, and obedient, loving and respectful santri/ wati. This soul makes santri always ready to fight in the way of God, wherever and whenever.

\section{Simplicity}

Life in Pesantren is overwhelmed by an atmosphere of simplicity. Simple doesn't mean passive, nor does it mean poor or destitute. It is precisely in the soul of simplicity that there are values of strength, ability, fortitude and self-mastery in the face of life's struggles. Behind this simplicity radiated a great soul, daring forward and unyielding in all circumstances. Even this is where life grows mentally and a strong character, which becomes the condition for struggle in all aspects of life.

\section{Self-sufficiency (Standing on Your Own Feet)}

Self-reliance or ability to help yourself is a powerful weapon that is supplied pesantren to its students. Self-reliance not only means that students can learn and practice taking care of all their own interests, but Pesantren itself as an educational institution must also be able to be independent so that it never rests its life on the help or mercy of others. This is the Zelp berdruiping system (both give dues and both use / use). Instead, pesantren is not rigid, so reject those who want to help. All the work in Pesantren is done by the managers and their own students. Through this soul radiated educational values that form the character of independence for students.

\section{Ukhuwwah Islamiyah}

Life in Pesantren is covered by a familiar fraternal atmosphere, so that all the joys and sorrows are felt together in the fabric of islamic ukhuwwah. There is no wall that can separate them. Ukhuwwah is not only during their time in Pesantren, but also influences towards the unity of the people in the community after they plunge in the community.

\section{Freedom}

Free in thinking and doing, free in determining the future, free in choosing the way of life, and even free from various negative influences from outside and society. This free soul will make santri / wati have a big-spirited and optimistic character in the face of all difficulties. It's just that in this freedom is often found negative elements, namely if the freedom is abused, so it is too free (liberal) and results in a loss of direction and purpose or principle. Freedom that becomes the soul of pesantren is what remains in positive lines and is still in the rails that God almighty, responsibly, both in the life of pesantren itself, and in the life of the community.

\section{B. Character Values Inherent in the Totality of Santri Life Activities in Pesantren}

1. Religious Character (Taqwa)

Actualized through istiqomah and mindful worship activities, such as praying 5 hours of congregation, sunnah qobliyah and ba'diyah, dhuha, tahajud, sunnah fasting, reciting the Qur'an, dhikr.

2. Independence 
Actualized through a series of daily activities that are done alone such as washing clothes, tidying up cabinets, cleaning the bed, determining how to learn, doing tasks, and other activities with the aim of getting used to not always relying on others.

3. Discipline

Actualized through obedience and adherence to the rules and values of kepondokpesantrenan and carrying out discipline in all activities and activities, such as displin dress, eating discipline, displin learning, discipline of worship, and so forth.

4. Care about the environment

Actualized through activities to maintain the cleanliness and beauty of the cottage environment, ranging from the environment of rooms, dormitories, classes, and surrounding courtyards to caring for existing plants and trees. Through the enactment of pickets and gotong royong activities, the santri are involved in cleaning and preservation activities of pesantren environment.

5. Creative

Diactualisaiskan through extracurricular activities in the development of interest in santri talent. Among the extracurricular activities that santri can participate in are scouting, art, skills, computers and sports.

6. Responsibility

Actualized through assignments that are assigned to santri, especially for students who sit in the management parts of student organizations (OPRH) and Scout Coordinators in carrying out the wheels of pesantren activities and santri discipline both in rooms, dormitories, and in mosques.

7. Tolerance

Actualized through the placement of various tribes and regions in one room, dormitory, and class with mutual respect and respect and do not discriminate. Although different characters and characters, the santri do not degrade each other let alone insult each other.

\section{Character Education Implementation Strategy at Pondok Pesantren Ar-Raudlatul Hasanah}

1. Through Teaching and Learning Activities in KMI Curriculum System

The strategy of implementing character education, if referring to Lickona's frame of mind which is considered as its bearer with the work The Return of Character Education and Educating for Character: How Our School Can Teach Respect and Responsibility, focuses on three main elements, namely how to know the good, then love it (desiring the good), and then do (doing the good). (Lickona, 1991) The three elements have an equal position so that they must be done simultaneously together to get optimal results at the same time maximum. A common mistake is to put knowledge of what is good only in the classrooms of learning, to love it enough in everyday attitudes (including outside the learning class), and to do as much as possible in everyday activities, most of which are not the case in learning classes.

The first step in understanding what character is desired from the curriculum content in Pesantren Ar-Raudlatul Hasanah can be done by observing the vision-mission and its derivatives. That's because the curriculum, both in language and terms like a track (curere-Greek) that connects between the purpose of the line (start) to the goal (finish). (Shaodih, 1997) Arabic literature refers to it as manhaj with a meaning that is not much different, namely the path of light as Al-Shaibani defines the curriculum as a path of light that must be taken by an educator in developing the potential of his learners, both in terms of knowledge, skills, attitudes and beliefs. (Asy-Shaibani, 1979)

Related to that, here is the vision-mission of Pesantren Ar-Raudlatul Hasanah:

"Vision: (1) Make the institution of Pesantren Ar-Raudlatul Hasanah as a quality institution of cadreization and community service, solely for worship to Allah SWT and expect His pleasure and implementation of the function of Allah's caliph on earth. (2) Cadreization of scholars and leaders of the ummah which is implemented in a structured and simultaneous manner through conducive miliu, as well 
as the service of forming superior and qualified individuals both as academics and practitioners reflected in innovative, creative and proactive attitudes towards the development of science."

"Mission: (1) Educate individuals who master the basic provisions of education, leadership and teachership and are willing and able to develop it to the most optimal level. (2) Preparing a superior and qualified generation towards the formation of khaira ummah generation. (3) Forming a generation of mutafaqqih fi ad-dîn and has intellectual traditions that are positive and responsive to the development and demands of the times, towards the creation of a learning society, and (4) Educate and form a generation of IQRA personalities ('Ilmy, Qur'any, Rabbany and 'Âlamy) who are ready to practice it in the midst of society with sincerity, intelligence and charity. Iqra combines the aspect of thought ('ilmy 'alamy) and the aspect of rabbany that is actualized in intelligence and religious morality."

Based on this information, it can be understood that Pesantren Ar-Raudlatul Hasanah is an educational institution that conducts the process of cadreization and ummah services in the field of education. The process of cadreization and service of the ummah in question is carried out by equipping its students about the basics of education, leadership, teachership, khaira ummah, mutafaqqih fi ad-dîn, intellectual traditions, learning society, and IQRA personality ('Ilmy, Qur'any, Rabbany and 'Âlamy). The ultimate goal (vision) that is expected is the emergence of a cadre of scholars and leaders of the ummah who are superior and qualified both as academics and practitioners who are reflected in an innovative, creative and proactive attitude towards the development of science. Therefore, the curriculum content that is set should have formulations that are not far from the ideas and concepts of the terms mentioned above.

As a deepening of the statement, the following will be displayed the lesson distribution data found in each class:

\begin{tabular}{|c|l|}
\hline CLASS & \multicolumn{1}{|c|}{ SUBJECT } \\
\hline I & $\begin{array}{l}\text { Arabic, Mahfudzat, Muthalaah, Imla', Khot, Fikih, Tawhid, Islamic Date, Qira'ah, } \\
\text { Tajwid, Tafsir, Hadith, Reading, Hisab, Indonesian, IPA, Mathematics, IPS }\end{array}$ \\
\hline II & $\begin{array}{l}\text { Bahasa Arab, Mahfudzat, Muthalaah, Imla', Khot, Fikih, Tauhid, Tarikh Islam, } \\
\text { Qira'ah, Tajwid, Tafsir, Hadis, Reading, Hisab, Bahasa Indonesia, IPA, } \\
\text { Matematika, IPS, Insya', Sharf, Nahwu, Tarjamah }\end{array}$ \\
\hline III & $\begin{array}{l}\text { Arabic, Mahfudzat, Muthalaah, Imla', Khot, Fikih, Tawhid, Islamic Date, Qira'ah, } \\
\text { Tajwid, Tafsir, Hadith, Reading, Hisab, Indonesian, IPA, Mathematics, IPS, Insya', } \\
\text { Sharf, Nahwu, Translation }\end{array}$ \\
\hline IV & $\begin{array}{l}\text { Mahfudzat, Muthalaah, Fikih, Tawhid, Islamic Date, Tafsir, Hadith, Reading, } \\
\text { Tamrinat, Mathematics, Insya', Sharf, Nahwu, Usul Fiqh, Indonesian, Balaghah, } \\
\text { Dinul Islam, Grammar, Tarbiyah, Economics (IPS), Geography (IPS), Sociology } \\
\text { (IPS), Physics (IPA), Chemistry (IPA), Biology (IPA), Tarikh Tasyri' (Religion), } \\
\text { Ulumul Quran (Religion) }\end{array}$ \\
\hline V & $\begin{array}{l}\text { Mahfudzat, Muthalaah, Fikih, Tawhid, Islamic Date, Tafsir, Hadith, Reading, } \\
\text { Tamrinat, Mathematics, Insya', Sharf, Nahwu, Usul Fiqh, Indonesian, Balaghah, } \\
\text { Dinul Islam, Grammar, Tarbiyah, Economics (IPS), Geography (IPS), Sociology } \\
\text { (IPS), Physics (IPA), Chemistry (IPA), Biology (IPA), Tarikh Tasyri' (Religion), } \\
\text { Ulumul Quran (Religion) }\end{array}$ \\
\hline VI & $\begin{array}{l}\text { Mantiq, Muthalaah, Fikih, Tawhid, Tafsir, Hadith, Reading, Ayatul Ahkam, } \\
\text { Mathematics, Insya', Sharf, Nahwu, Usul Fiqh, Balaghah, Indonesian, Adyan, } \\
\text { Grammar, Tarbiyah, Economics (IPS), Geography (IPS), Sociology (IPS), Physics } \\
\text { (IPA), Chemistry (IPA), Biology (IPA), Tasyri Date' (Religion), Ulumul Quran } \\
\text { (Agama), Tarik wa Al-Hadharah (Religion), Mushtalah Hadith, Accounting (IPS), } \\
\text { Akhlak (Agama), Milal wa Nihal (Religion), PKN (IPS), History (IPS) }\end{array}$ \\
\hline
\end{tabular}


Distribution data as seen above, in the internal study of Pesantren Ar-Raudlatul Hasanah, is considered qualified to equip students to arrive at the ideas and concepts that exist in the vision-mission and its derivatives. To give some examples of the basics of education, subjects such as tawhid, tafsir, hadith and jurisprudent appear in every class. This material is certainly commonly known as the basics of Islamic religious science. From it developed advanced scientific materials such as tajwid (class $1 \& 2$ ), dinul Islam (3-4), adyan (5-6), ulumul Quran (4-6), Usul Fiqh (3-6), faraidh (3), mushtalah hadith (5-6), Tarikh tasyri' (4-6), ayatul ahkam (6), akhlak (6) and Milal Wa Nihal (6).

For the basics of leadership, there are no specific subjects as the basics of education above. It's just that, in teaching material, knowledge of leadership appears as in the lessons of Muthala'ah, Tafsir, Hadith and Mahfuzhat. In the 5th grade muthalaah, for example, there are three titles that talk about leadership namely Kullukum Ra' wa Kullukum Mas'ul 'an Ra'iyyatih $(1,2,3)$ which is thahir bin alHusain's advice quote for his son Abdullah bin Thahir when charged with serving as governor in Raqqah and Egypt and the areas around both. In the material it is explained that a leader must be fair, decisive, defender and give of security and comfort to his community (Title 1). A leader does not need to dissolve into mistakes, malice, past evils so as to stop doing good in the future (title 2). The leader must be careful of the advantages of others so as to be able to imitate them and imitate their goodness (title 3 ).

Thus furthermore in the teachership (Tarbiyah class 3-6), khaira ummah (material), mutafaqqih fi ad-dîn (the same as the basics of education), intellectual traditions (all pesantren lessons), learning society (tarbiyah 3-6, including sociology 4-6), and iqra personality ('Ilmy, Qur'any, Rabbany and 'Âlamy). Especially for 'Âlamy, its meaning is its benefits globally that can be bridged with language sciences (Arabic, Nahwu, Sharaf, Balaghah, Indonesian, Reading, and so on). In general, characters educated on the content of the curriculum, can be detailed as follows: (Zarkasyi, 2011).

\begin{tabular}{|l|l|l|}
\hline No & Character & \multicolumn{1}{c|}{ Material Overview } \\
\hline 1 & Sincerely & $\begin{array}{l}\text { Sincerity is the spirit of every activity in Pesantren, in learning classes and } \\
\text { outside. As for the learning class, among them, the picture of the material is in } \\
\text { the Muthalaah Lesson entitled Ikhlas, explained that "performance is like a } \\
\text { body while the spirit is sincere. Just as a body that will not stand if separated } \\
\text { from the spirit, then performance will not be valuable if it is not done } \\
\text { sincerely." } \\
\text { Another picture that can be grouped into this is the implementation of } \\
\text { afternoon teaching practices for class I-II which is mastered by class V-VI with } \\
\text { monitoring from a teacher. In this case, everything is done sincerely selflessly. }\end{array}$ \\
\hline 2 & $\begin{array}{l}\text { The attitude of initiative can be seen in the practice of using Arabic and } \\
\text { English. The materials and hours of lessons provided certainly cannot fulfill } \\
\text { every word required by the santri. Teachers in this case ask the students to take } \\
\text { the initiative to find vocabulary that is difficult to understand in the dictionary } \\
\text { of the language that can be owned. This attitude can also be seen in the } \\
\text { development of teaching techniques in tarbiyah lessons mainly in teaching } \\
\text { practice activities. }\end{array}$ \\
\hline 3 & $\begin{array}{l}\text { Some of the subject matter demands cooperation and a mature social spirit in } \\
\text { santri-santri. Arabic, for example, has muhâdatsah material that requires two or } \\
\text { three students to talk about one big theme in practicing their language style. } \\
\text { The same is also appeared in IPA lessons, especially in practicum sessions, } \\
\text { where the trials demanded were not individual but santri groups. }\end{array}$ \\
\hline Communicative & $\begin{array}{l}\text { Khot lessons are arabic writing lessons in accordance with the correct rules. } \\
\text { These lessons are only given in class I-III although writing obligations remain } \\
\text { up to class VI in each of their lessons. Restriction of material to class III alone } \\
\text { is an attitude of believing that students in the next classes will continue to learn } \\
\text { and practice because they already know and understand how the rules. }\end{array}$ \\
\hline Trustworthy
\end{tabular}




\begin{tabular}{|c|c|c|}
\hline 5 & Struggle & $\begin{array}{l}\text { Knowledge about hard work is very popular in Pesantren through mahfudzot } \\
\text { lessons taught in the first year of Pesantren, namely man jadda wajada - } \\
\text { whoever means it will get. }\end{array}$ \\
\hline 6 & $\begin{array}{l}\text { Mastering the } \\
\text { Problem }\end{array}$ & $\begin{array}{l}\text { The contents of lessons in Pesantren often require students to learn } \\
\text { independently in addition to studying in the classroom. Lessons such as } \\
\text { muthalaah, mahfuzhat, hadith, tafsir, jurisprudence and so on are often } \\
\text { explored through informal discussions between fellow students. In this case, it } \\
\text { is actually seen that the content in the lessons hones the santri skills to master } \\
\text { the charge and find the solution in their own way. }\end{array}$ \\
\hline 7 & Integrity & $\begin{array}{l}\text { Integrity that is first seen in the curriculum content is the connectedness } \\
\text { between one lesson with another. That is, each distributed subject matter does } \\
\text { not overlap with each other. Biology lessons, for example, that have a material } \\
\text { charge about human reproduction are not necessarily released on } \\
\text { comprehension can only be done by frilling the ovum with sperm only, but } \\
\text { also explained about God's permission for human existence. It is also found in } \\
\text { economics lessons that commonly mean human needs at the primary, } \\
\text { secondary and tertiary levels, which are material. In fact, a more basic need is } \\
\text { about worship taught in the QS interpretation lesson. Adz-Dzariyat } 56 \text {. }\end{array}$ \\
\hline 8 & $\begin{array}{l}\text { Have Guts and } \\
\text { Aren't Afraid } \\
\text { of Risk }\end{array}$ & $\begin{array}{l}\text { Language lessons demand guts and are not afraid of risks in applying them. In } \\
\text { language lessons, teachers are required to invite students to shout together } \\
\text { vocabulary they do not understand to then require them to use it in everyday } \\
\text { life. This certainly hones the guts of every santri at the risk of there being a } \\
\text { friend who fixes - if wrong, even mocking. It is precisely those who mock it } \\
\text { who will be punished in Pesantren because it can damage the guts of other } \\
\text { santri. }\end{array}$ \\
\hline 9 & $\begin{array}{l}\text { Honest and } \\
\text { Open Minded }\end{array}$ & $\begin{array}{l}\text { The connectedness between one teaching material and the next requires each } \\
\text { santri to be honest and open in their understanding. This honest attitude will } \\
\text { arise when each lesson begins with a question about the previous lesson so that } \\
\text { it is known santri-santri who understand well and santri-santri who do not } \\
\text { understand well. This honest attitude is also contained in mahfudzot or } \\
\text { muthalaah subject matter such as the word 'the base of sin is a lie' and the story } \\
\text { of 'honesty reply' that brings benefits. }\end{array}$ \\
\hline 10 & $\begin{array}{l}\text { Ready } \\
\text { sacrifice }\end{array}$ & $\begin{array}{l}\text { The curriculum content that has been set by Pesantren cannot be bargained to } \\
\text { be mastered as a whole. Minimal mastery will be judged at a minimum as the } \\
\text { maximum mastery of maximum value. In Pesantren, values with the numbers } 1 \\
\text { to } 10 \text { are applied purely with the intention of sharpening themselves to } \\
\text { sacrifice their efforts to get the same thing. In the lesson muthalaah also found } \\
\text { the expression derived from the Qur'an, namely 'the reward of every evil is a } \\
\text { worthy evil'. In the lesson mahfudhat is also taught that 'whoever does the } \\
\text { unjust will get a reply to the tyranny'. }\end{array}$ \\
\hline
\end{tabular}

The above information is an illustration of how to know the good (knowing the good) in Lickona theory (Lickona, 1991) to then love it (desiring the good) in the implementation of the curriculum, and then do (doing the good) in daily activities.

\section{Through Pesantren Extracurricular Activities}

The extracurricular curriculum at Pondok Pesantren Raudlatul Hasanah Medan is carried out outside school hours under the guidance of teachers and administrators of santri organizations, as well as senior students. Character education through extracurricular activities is a conscious effort designed and implemented by educators to shape, strengthen, and develop distinctive values. As for the various extracurricular activities at Pesantren Ar-Raudlatul Hasanah Medan, namely; a) Assessment of Classical 
Literature, b) Scientific Study Group, c) Journalistic Training, d) Teaching Practice, e) Scouting, f) Computers, g) Marching Band, h) Arts and Skills, i) Hajj Manasik, j) Corpse Management, k) Sports and Martial Arts Clubs.

In addition to being a means of self-development and interest in santri talent, the extracurricular activities of Pesantren Ar-Raudlatul Hasanah also have a community orientation, because the students are prepared to plunge in the midst of society.

a. Study of Classical Literature (Fathul Kutub)

In general, Pesantren is indeed known as an Islamic educational institution that examines classical literature relics of scholars or popularly referred to as the yellow book. It's just that, in Modern pesantren such as Pesantren Ar-Raudlatul Hasanah, the implementation is not as focused on classes as traditional pesantren to find that it becomes a temporal program. The material that is discussed in this activity called Fathul Kutub is: Fiqh, Tawhid, Hadith and Tafsir. This activity is held for a week every year with participants who are devoted to class $\mathrm{V}$ santri / santriwati who are divided into several groups.

Each group will be charged to discuss certain materials under a musyrif consisting of ustadz and ustadzah. The material discussed is what develops in the community, such as how the law of zakat nonMuslim, what is the law of apostates, what the prophet said that explains the ordinance of tarawih prayer and how the interpretation of scholars about the leadership of non-Muslims. That way, moral knowing santri awakened in this program which further grows the character of love towards scholars that can also be understood as a love of Islamic traditions despite living in a global age.

b. Leadership education and organizationalization

Organizational activities at Ar-Raudlatul Hasanah boarding school become the right means in training and educating leadership for students. This organizational activity is an inseparable activity from daily santri life, because organizing in pesantren, indirectly means educated students to take care of themselves and of course others. The whole life of santri while in the hut is arranged by themselves by being guided by teachers.

Santri organizational exercises can be found on both micro and macro scales. Leadership and organizational education on a micro scale for students can be found in the practice of being the chairperson of rooms in dormitories / rayon, class chairmen, club chairmen, consulate chairmen, and dormitory / rayon chairmen (youth specifically for class V) in which there is a dynamics of stewardship (organization), ideas, movements. Then leadership education and organizational in the macro environment can be found in the form of Student Organization Ar-Raudlatul Hasanah (OPRH) and Scout Movement. OPRH is an intrasantric organization, the implementers of this organization are the final class santri-santri (class V and VI) who are democratically elected and guided. OPRH managers and coordinators must be responsible for all activities and finances of the organization whose value is not small. At the end of the term, they report on activity and financial liability during the stewardship period, before being replaced by the next administrator. This is where the value of sincerity, integrity, and responsibility is awakened in the santri.

\section{c. Teaching Practices (Tarbiyah Amaliyah)}

Teaching prowess is actually the spirit of the Pesantren curriculum which reads Kulliyatul Mu'allimin al-Islamiyah; The seedlings of Islamic teachers. The teaching practice program is the finalization of the provisions that have been instilled from each activity. Therefore, it is intended for the end of KMI class VI. The form of implementation is to become a teacher in a day with assessments from colleagues and guidance teachers. Each student will be given one material for one class that has not been taught by the teacher. Santri will be galvanized for 2 weeks with solid activities to add insight and their 
mastery of teacher training. That way, teaching practice activities will teach students how to make teaching preparations, then teach them to be evaluated together. Through this activity, there are four things that want to be transformed to santri-santriwati, (1) develop the spirit of teachership, (2) foster the spirit of sharing knowledge, (3) foster the spirit in tafaqquh fil 'ilmi, (4) mature the skills of Arabic and English

\section{d. Scouting}

Scouting although labeled as an extracurricular activity, but for all students of Pesantren ArRaudlatul Hasanah from grades I to VI is required to follow it every Thursday. Scouting activities are often understood as a forum for mental education and leadership. In addition, scouting activities in pesantren also become one of the powerful means in the formation of nationalism, including through ceremonial activities and line-marching. Scouts build various things related to character formation and the development of good attitudes such as obedience to God, love for nature, to fellow humans. Through this activity also, santri is trained to be disciplined, responsible, independent and in solidarity between one team squad. In addition, scouting becomes a means of training courage and teaching how to rely on emotional intelligence that is able to influence the attitude of santri.

\section{e. Speech Training (Muhadharah)}

The implementation of speech training (muhadharah) in pesantren is divided into three times, namely every Sunday night for English, Thursday afternoon before scouting for Arabic, and Thursday night for Indonesian. This speech training activity trains students to learn to convey religious messages using rhetoric and communication styles like a Da'i. In addition, this activity is also a means of improving the ability of foreign languages (Arabic and English) of students. Moreover, the speech training activities become a place to prepare students to later serve in the midst of society, especially in preaching through religious languages.

\section{f. Entrepreneurship}

The entrepreneurial exercise carried out by students at Ar-Raudlatul Hasanah boarding school is to manage pesantren business units in the form of Student Shops, Student Stalls, and Laundry Sections which are all members of the Ar-Raudlatul Hasanah Student Organization (OPRH). Santri who is assigned to run the management of parts of the business unit is a santri that has occupied the final level class that starts from class V. In addition to supporting the independence of pesantren as the soul of pesantren is independent, managing the pesantren business unit is also a container in educating independent and honest character for students

g. Scientific study groups, marching bands, arts, skills, sports clubs, and martial arts

These activities are a development of different interests and talents. For example, there is a group of scientific studies directed to students who like to learn which is channeled by the existence of islamic economic study groups, physics, fiqh, hadith, tafsir, morals and so on. Likewise with the art of music, calligraphy, painting, used goods (handycraff) which belongs to the group of arts and skills. Sports clubs and martial arts can also be understood in such a way. All activities included in this section are carried out separately at the same time, namely after ashar prayer (16.30 WIB) until before the afternoon bath (17.30 WIB) every day. Santri is required to comply with the rules and regulations that have been made. From these activities, built the values of discipline character, love of science, love of beauty, creative, and sportsmanship.

\section{Through Pesantren Culture/ Culture}

In Pondok Pesantren, pesantren culture has been created since the pesantren was established until now. Sincere, simple, independent culture, ukhuwwah Islamiyyah, and freedom is a culture that has been 
reformed for generations in a pesantren environment. Pesantren culture is formed from a program of activities that are arranged then there is an intervention process to students both from daily, weekly, monthly, and annual activities. All these activities are carried out to form the character of santri so that the students are accustomed to the routine that is formulated so that then created a distinctive culture that is different from the school cultures that exist outside the pesantren. In this case, the advantage of pesantren in character formation lies in its dormitory system that allows pesantren to apply courcurricular and extracurricular learning to all pesantren residents.

The development of pesantren culture and learning centers is carried out through various santri self-development activities that become routine in santri life. Routine activities integrated with couricurricular and extracurricular activities are activities organized through a systematic framework aimed at educating students have a character in the form of mental readiness of life, and good akhklak. This is in line with Hasan's view that systematic activities will facilitate in shaping the character of learners because the development of human character as a young generation can be achieved with various educational instruments that are carried out in a programmable, gradual, and continuous manner (Hasan, 2010).

Activities are designed to be structured from waking up early to bedtime continuously and consistently at all times. In this case, the totality of santri life in pesantren can not be separated from the practice of the values of the soul and the motto of pesantren which became the foundation of the formation of santri character. All activities that support character education, of course, are facilitated with the tools of guidelines for the implementation and development of human resource capacity. For this reason, Pesantren Ar-Raudatul Hasanah designed the time according to the needs of the implementation of activities that educate the character of santri contained in: (1) daily activities (2) weekly activities (3) annual activities.

\section{a. Daily Activities}

At Ar-Raudlatul Hasanah boarding school, character education is implemented through daily activities for a full 24 hours starting from waking up and even going back to sleep. For daily santri both in rooms, dormitories, classes, and in the pesantren environment is required to maintain their attitude and behavior. Santri is always able to get used to independence, discipline, leadership, help, responsibility, responsiveness, and caring. Everything that exists and takes place in pesantren contains educational values in shaping the character of santri. In the pesantren environment, santri not only learn about good character, santri see, hear, and feel which is further required to be able to practice good characters directly. Pesantren becomes a conducive environment for the education of its santri-santri character. Here's the daily schedule of activities: begin from 04.30 a.m wake up in the morning, congregational Shubuh prayers, giving new vocabulary and morning showers, breakfast, learning in the class, out of class continued Zuhur prayer congregation, lunch, learning in the class of tutoring, out of the class of tutoring, praying Ashar together, sport, bathe, goint to the mosque to read the Qur'an, dinner, Isya prayer congregation, repeating the lesson, and at 10.00 p.m going to bed to sleep at night.

\section{b. Weekly activities}

Weekly activities followed by santri include activities on Friday morning, namely Muhadatsah / Morning Conversation followed by morning running / gymnastics. For Sunday night activities, namely English speech exercises, while On Thursday afternoons, santri follow Arabic speech exercises followed by scouting exercises, and Thursday nights santri follow speech exercises Indonesian. In addition to selfdevelopment related to interests, talents, and skills, the weekly activities also contain contents of character values such as discipline, strong will, persistent, commitment, respect for others, and self-confiden. 


\section{c. Annual Activities}

Annual activities involving santri such as Annual Apple and Khutbatul Arsy Introduction Week, Khutbatul 'Arsy Public Lecture, Happy Stage Performance (Santri Class VI), Pargelaran Drama Arena (Santri Class V), Reading of Order and Discipline (Ten Commandments), Sports and Arts Week (Porseni), Scout Movement Jamboree, Drama Competition and Vocal Group Between Rayon, Art Expo, Work Deliberations and Reports, Accountability of OPRH and Coordinator, Scouting, Celebration of Eid al-Adha \& Slaughter of Sacrificial Animals, and Islamic New Year Celebration 1 Muharam

Good practices in routine activities both daily, weekly and annual activities are carried out continuously and consistently through the intervention of pesantren cultural settings / culture in creating a miliu or community-based learning environment (learning Society) for the benefit of the santri character education process, so that all what is seen, heard, done, and felt by students contains educational values.

The activities mentioned above are deliberately designed and carried out on a scheduled, structured, and system with the aim of getting used to students doing good practices that then form character so that students will be accustomed to doing good and positive things not only when in the pesantren environment, but also when they are in the family and community environment.

As Az Zafi in his writing explained that character education in pesantren is actually fostering good habits, so that santri can understand (cognitive), feel (affective) and do (psychomotor) good behavior. Character education not only concerns aspects of the good of knowledge (moral knowing), but also love kindness (moral feeling), and good behavior (moral action). Character education puts forward habits that are always done and practiced every day (Zafi, 2021).

The implementation of character education in Raudlatul Hasanah pesantren can not be separated from the most essential values, namely, the soul and motto of Raudlatul Hasanah pesantren. Methods used in shaping the character of the santri through directing, transparency, assignment, habituation, and training. These methods are presented in carrying out good character education that is contained in the totality of curricular activities and activities, as well as extracurricular. Character education in Raudlatul Hasanah pesantren has been designed and systemized in such a way that is interpreted by the system of instilling character values to all students, and every individual who shelters in it through the approach of pesantren structure and culture.

The implementation of integrated character education in teaching and learning activities, extracurricular activities, and pesantren culture/culture as previously described was taken through the application of a number of methods, namely:

\section{a. Briefing}

In the process of implementing character education for students at Pondok Pesantren Raudlatul Hasanah, the delivery of directions to students before participating in various extracurricular activities and activities becomes something absolute and even mandatory. In this case, santri is given an understanding so that they understand what to carry out the activity, how to carry it out, and what the contents and philosophies in it so that santri does not just participate in carrying out activities. The principle of moral knowing is the first step and is considered important that must be done in applying character education in pesantren.

b. Exemplary

The values raised from the activities of students, teachers, and all the residents of the boarding school are actually what educates. From here the creation of the so-called learning society (learning society), and from here also mental attitude will be embedded. In this case, the significance of the 
function of the leader (kyai), teachers, supervisors, managers of the organization becomes absolute in playing the role of example (uswah hasanah). So the characteristics of role models become a reflection in presenting values in the form of sincerity, simplicity, earnestness, breadth of insight and science, courage, firmness, idealism, visionary, trustworthy, honest, and transparent into a unity of uswah hasanah which in turn will be a reflection in the formation of santri character.

\section{c. Assignment}

In the modern pesantren education system including in raudlatul hasanah boarding school, there are many kinds of assignments such as being a student organization manager (OPRH), scouting manager, rayon manager, club manager, and scouting. This assignment is done as a means of educating the character of santri, especially the character of discipline, responsibility, trust, courage and firmness. With this too, santri will be trained, educated, controlled, and motivated. Thus, the assignment becomes a means of leadership education for students in Pesantren Raudlatul Hasanah. With the task given, students can explore their potential and abilities, especially in developing leadership skills and solving various problems.

\section{d. Training}

In the implementation of character education, Pesantren Raudlatul Hasanah includes its students in various training processes to develop the potential, skills, and interests of santri talent so as to build a high sense of trust to continue to achieve achievements. Therefore, the participation of santri in the training process fosters and forms the mental and character of santri. The existing training includes organizational training both at the dormitory level and in student organizations, scouting training, speech training (muhadharah), courses, sports and arts clubs, and so on.

\section{e. Habituation}

Habituation in Raudlatul Hasanah boarding school is a typical and vital method, applied by doing the process of activities repeatedly aimed at making santri become accustomed to behave, behave, and think relatively settled which ultimately develops the character of santri. At this stage, santri are accustomed to doing good values even though they do not yet understand the meaning of these values. Interestingly, sometimes santri in starting the habituation process needs to start with coercion. In everyday life, for example, the santri are accustomed to waking up at dawn, praying at dawn, and reading the Qur'an. From morning to evening, students carry out learning activities with teachers in the classroom. At night, santri is accustomed to night study in a guided manner.

\section{f. Discipline}

Discipline is a very important component in the implementation of education in pesantren, especially modern pesantren. Santri discipline in both curricular and extracurricular activities and daily routines becomes a powerful method in order to educate the character of santri in Pesantren Raudlatul Hasanah, especially the character of discipline. Instruments in cultivating the character of discipline include in the form of written rules, in addition to the unwritten ones that must be carried out by students such as discipline in worship, learning, boarding, dressing, and exercising.

\section{g. Rewards and Punishments}

Appreciation is a method needed as a stimulus for the development of santri in a better direction. The provision of punishment is a form of the enactment of the consequences of violations committed by santri as a warning of the agreed regulations. The punishment given is constructive and remains loaded with educational values. The target of this method is for students to practice carrying out responsibilities 
in their lives. In addition, mental santri will also be trained to dare to admit mistakes and be ready to be corrected and improved.

\section{Conclusion}

All components of education in the formation of santri character in Pondok Pesantren Modern ArRaudlatul Hasanah Medan have a strong relationship between each other which is built systematically and integrated. The application of character education covers the overall totality of education ranging from the learning process, pesantren management, and daily activities. At Pondok Pesantren Modern Ar-Raudlatul Hasanah, character values are integrated into subjects, extracurricular activities, and culture through the creation of educational susana or environment (bi'ah). In this case synergy and coherence between culture and structure becomes a determining factor in the success of the implementation of character education in modern pesantren educational institutions.

\section{References}

Asy-Syaibani, O. M. (1979). Falsafah Pendidikan Islam. Jakarta: Bulan Bintang.

Fakhruddin, A. (2014). Urgensi Pendidikan Nilai Untuk Memecahkan Problematika Nilai Dalam Konteks Pendidikan Persekolahan. Jurnal Pendidikan Agama Islam-Ta'lim, 12(1), 79-96.

Guntur, M. a. (2017). Implementasi Kebijakan Pendidikan Karakter Terhadap Pengaruh Globalisasi. Seminar Nasional Sarjana Ilmu-Ilmu Sosial, (pp. 231-238). Makassar.

Hasan. (2010). Pengembangan Pendidikan Budaya dan Karakter Bangsa. Jakarta: Litbang Puskur.

Lickona, T. (1991). Educating for Character: How Our School Can Teach Respect and Responsibility. New York: Bantam Books.

Rasdi Ekosiswoyo, e. (2017). The Integration of Local Cultural Wisdom in Building The Character Education of Students. International Journal of Education and Research, 153.

Rusman. (2012). Model-Model Pembelajaran . Jakarta: Raja Grasindo Persada.

Suryadi, A. (2012). Pembangunan Pendidikan Indonesia: Menuju Kualitas Yang Berdaya Saing Secara Global (The Indonesian Education Outlook 2025: Toward A Sustainable World Class Quality Level). Jakarta: Badan Penelitian dan Pengembangan Kementerian Pendidikan dan Kebudayaan.

Syaodih, N. S. (1997). Prinsip dan Pengembangan Kurikulum. Jakarta: P2PLTK.

Zafi, A. A. (2021). Character Building In Pondok Pesantren Algurobaa'. Al-Insyiroh, 7(2), 26.

Zarkasyi, A. S. (2011). Bekal Untuk Pemimpin: Pengalaman Memimpin Gontor.Ponorogo:Trimurti Press.

Zuchdi, D. (2010). Pengembangan Model Pendidikan Karakter Terintegrasi Dalam Pembelajaran Bidang Studi Di Sekolah Dasar. Jurnal Cakrawala Pendidikan, 1-12

\section{Copyrights}

Copyright for this article is retained by the author(s), with first publication rights granted to the journal.

This is an open-access article distributed under the terms and conditions of the Creative Commons Attribution license (http://creativecommons.org/licenses/by/4.0/). 